\title{
Why not Belhar? Some Reflections on the Foremost Barrier in the Process of Church Reunification
}

\author{
Eugene A Fortein \\ https://orcid.org/0000-0002-5592-5145 \\ University of the Free State \\ ForteinEA@ufs.ac.za
}

\begin{abstract}
The Belhar Confession is perhaps the most significant barrier in the process of church reunification in South Africa. This article reflects upon the critique voiced against Belhar by the DRC and opponents of the confession. The critique against Belhar mainly focuses on the issues that it confesses no new beliefs, the setting of its origin and its connection with black theology. This study indicates that Belhar, like the other Reformed confessions, confessed no new beliefs and originated within a particular context, but is not bound to that context. The study further indicates how Belhar embodies the black experience through the hermeneutical elements of black theology.
\end{abstract}

Keywords: Belhar Confession; apartheid; reformed tradition; Dutch Reformed Church; Dutch Reformed Mission Church; Uniting Reformed Church

\section{UNISA}

Studia Historiae Ecclesiasticae https://upjournals.co.za/index.php/SHE/index Volume 47 | Number 1 | 2021 | \#9068 | 17 pages https://doi.org/10.25159/2412-4265/9068 ISSN 2412-4265(Online)ISSN 1017-0499(Print)

(C) The Author(s) 2021 


\section{Introduction}

This year marks the 35th anniversary of the Belhar Confession. The drafting of a theological confession is not an occurrence that transpires habitually or without contemplation. It is a rare occurrence. One can understand the surprise, even shock, when the then Dutch Reformed Mission Church ${ }^{1}$ (hereafter DRMC) decided to draft a new confession at her synod in 1982, after the World Alliance of Reformed Church's (hereafter WARC) announcement of a status confessionis. ${ }^{2}$ The Belhar Confession (hereafter Belhar) was the first confession of faith to be formulated in almost 300 years within the Reformed tradition and the first to be formulated in Africa (Boesak 2011, 144). Since then, Belhar has been a contentious issue and the nub of theological discourse within the Dutch Reformed family of churches, with critique coming from far and wide. This article offers some reflections to explicate how Belhar is the most significant barrier in the reunification process in South Africa. ${ }^{3}$ This article will investigate the rationale put forward by the Dutch Reformed Church (hereafter DRC) on various occasions as to why reunification cannot come to pass, with a specific focus on the DRC's rejection of Belhar.

The DRC ruled in 1990 that Belhar does not conflict with the Three Forms of Unity, but Belhar was nevertheless not accepted as a confession (Acts of General Synod of Dutch Reformed Church 1990, 707). The Dutch Reformed Church in Africa (hereafter DRCA) accepted Belhar in full in 1991. After the DRMC and DRCA had merged in 1994 to form the Uniting Reformed Church in Southern Africa (hereafter URCSA), a large number of congregations of the DRCA (more than 140) decided not to participate in the merging of the two churches, to continue as DRCA and not to endorse Belhar.

The critique against Belhar is no new occurrence. Since the birth of the confession in 1986, the DRMC (now URCSA) has been in continuous dialogue to uphold and defend the status of Belhar as a full-fledged confession. However, Belhar has come increasingly under the spotlight since the DRC decided to amend article 1 of the church order at the General Synod in $2013 .{ }^{4}$ It is usually during these robust conversations on church reunification that the most critique against Belhar is aired. Was a confession truly necessary? Why not just a theological statement? What does the acceptance of a new confession say about the traditional confessions of faith and their content? These are

1 The Dutch Reformed Mission Church (DRMC) was established in 1881 as a separate racially-based church for the coloured constituency of the population.

2 See Cloete and Smit for a thorough discussion on status confessionis in Cloete and Smit 1984. A Moment of Truth: The Confession of the Dutch Reformed Mission Church 1982. Grand Rapids, Michigan: Eerdmans.

3 The article does not claim that Belhar is the only barrier when it comes to church reunification. However, most conversations in the DRC around church reunification focus on Belhar.

4 The amended article 1 reads as follows, "Die Belydenis van Belhar is deel van die belydenisgrondslag van die kerk, op so ' $n$ wyse dat daar ruimte is vir lidmate, ampsdraers en vergaderinge wat dit as in ooreenstemming met die Woord van God bely, sowel as vir lidmate, ampsdraers en vergaderinge wat dit nie as 'n belydenisskrif onderskryf nie" (Dutch Reformed Church 2013, 16). 
just some of the questions aiming critique at Belhar. It seems that the lion's share of commentary comes from the more conservative constituency within the DRC, like the synod of the Free State, who voted overwhelmingly against the inclusion of the Belhar Confession in Article 1 of their church order (Die Kerkbode, 6 March 2015).

Some voices of critique, like that of Piet Strauss, even went as far as to question the DRMC's understanding of her very own tradition (Reformed tradition) by asking whether the DRMC Synod of 1982 understood the requirements that were necessary for formulating a new confession (Strauss 2005, 571). Strauss $(2005,571)$ further questions the synod's acquaintance with the content of her confessions of faith by asking if the synod knew what the existing Three Forms of Unity already declare on unity, justice and reconciliation, as articulated in Belhar. Despite these and other voices of critique, the DRMC/URCSA stood firm in her stance regarding Belhar and has shown that she is well equipped to interpret her own confessions and tradition. More so, in the form of Belhar, the DRMC/URCSA has demonstrated that she is more than capable of doing authentic contextual theology.

Du Plooy (2010, 353-354) shows how an official survey, conducted in 2007 in the DRC, indicated that although $68 \%$ of the DRC ministers are in favour of unity with URCSA, only $48 \%$ of them are willing to accept Belhar as an official confession. After several failed unity talks between the DRC and URCSA and the DRC's failure to adjoin Belhar in their current confessional basis, the 2008 General Synod of URCSA placed a moratorium on further talks, unless the World Alliance of Reformed Churches mediate the conversation, and demanded that the acceptance of Belhar is a condition for unity (Agenda en Handelinge VGKSA 2008, 194). These events accentuate the argument that not only has Belhar become synonymous with the debate on church reunification, it is also perhaps the most significant barrier in the entire process.

The article will discuss three points of critique in the DRC's objections: Belhar confesses nothing new, its socio-political origins, and its connection with black theology. This article will conclude with a focus on the question: Why not Belhar?

\section{Critique against Belhar: Nothing New}

Among the various critiques of Belhar, none emerges more frequently than the observation that the confession confesses nothing new. The opponents of Belhar are quick to emphasise that the existing Three Forms of Unity speak adequately on the issues of unity, reconciliation and justice, and therefore Belhar does not contribute new insights.

A study conducted by a master's degree student (Cornelissen 2013) at the University of the Free State under the supervision of Professor Piet Strauss on the topic, "Die Debat rondom die Belhar-Belydenis: 'n Studie van Argumente," reiterated critique at Belhar. In this study, Cornelissen aims to address the polarisation within the DRC regarding the adoption of Belhar as a confession of faith. He believes the confession that asserts unity 
will eventually cause division within the DRC (Cornelissen 2013, 12). Cornelissen continues by scrutinising Belhar in its entirety. On the subject of whether Belhar confesses new issues, Cornelissen answers a clear "no" (Cornelissen 2013, 140). According to Cornelissen, the only difference between Belhar and the existing Three Forms of Unity is that Belhar places more emphasis on the horizontal tendency than the vertical tendency. He asserts further that the adjustment in the accent from the horizontal to the vertical is no rationale for a formulation of a new confession (Cornelissen 2013, 140). Strauss $(1997,13)$ shares the same concern: Belhar is not about the main issues of doctrine and Scripture, but about marginal issues. The Christian tradition holds some respected confessions, but not all are concerned with doctrinal matters. Boesak (2011, 152) reminds us that the first known confession of the Christian church ("Jesus is Lord"), was not made as a doctrinal statement but as a living testimony against an idolatrous Roman state and the claims of the divinity of the Roman Caesars.

Strauss $(2005,570-571)$ goes further than Cornelissen in stating that the existing Three Forms of Unity are, in certain areas, even more apparent on the issues of unity, justice and reconciliation and that the content of Belhar could have been presented in a declaration. According to Botman $(2008,15)$, Belhar widens the Three Forms of Unity ownership to black and white in Reformed churches worldwide. He states that Belhar contributes significantly to the nature of Reformed confessional statements by including the idea that Christians can derive confessional affirmations from social ethics. Belhar contributes to and complements the existing Three Forms of Unity in an explicit confession of faith in God as a God of Justice. Belhar closes a loophole in Reformed confessions by confessing that God is revealed as the One who brings justice and genuine peace among human beings (Botman 2008, 16). Belhar makes a further contribution to the Three Forms of Unity, confessing that in a world of injustice and enmity, God is, in a special way, revealed as the God of those who suffer, especially of those who suffer as a result of poverty and injustices.

Is the task of confessions only to confess novel theological truths? Can Belhar be discarded on this view of Strauss alone? Strauss (2006) answers these issues and more in an article entitled, "Skrif, Belydenis en die Aard van Kerkverband" where he recounts the critical task of Reformed confessions. He asserts that the DRC, at her General Synod in 1998, again reiterated that the authority of the existing Three Forms of Unity is seated in the fashion they formulate Reformed beliefs (Strauss 2006, 107). He argues further that they are authoritative in the manner they correspond with Holy Scripture. Their authority rests in the beliefs that they want to confess according to Holy Scripture and, in that way, foster unity among believers. Strauss $(2006,108)$ mentions an interesting observation that the crux of the faith community's faith is confessed from the hearts of the believers. This is indeed true of the Three Forms of Unity.

The Confessio Belgica (1561) was a comprehensive statement of the Reformed faith during the Spanish inquisition, when Guido de Brés was pleading for understanding and toleration from King Philip II of Spain. The origins of the Confessio Belgica were not 
merely for religious reasons. The intention was, among other things, to mainly show the Roman public and Roman leadership of the time that the Calvinist movement has a nonrevolutionary spirit. This was when King Philip II was determined to root out all Protestants, and the Reformed faith needed to be explained and defended. Correspondingly, Belhar aims to defend and uphold both the credibility of the gospel of Jesus Christ and the heart of the Reformed faith.

Similarly, the Canons of Dort sought to settle a severe controversy brought on by the rise of the heresy of Arminianism ${ }^{5}$ amidst great political and theological conflict in the Netherlands. The conflict arose around the topic of election, whether salvation was just pure grace. Botha and Naudé $(1998,15)$, in their On Route with Belhar (Op Pad met Belhar), illustrate how the Canons of Dordt (hereafter Dordt) reject the heresies connected to Anabaptists and the Roman Catholics. It is noteworthy that the 1978 synod of the DRMC, ABRECSA and the WARC declared apartheid a heresy. Like Dordt, Belhar rejects the heresy of apartheid and is "the shibboleth that distinguishes between the true church and the heretical church; it was a call for repentance" (Horn 2013, 162).

The Heidelberg Catechism, similarly to Belhar, emerged out of a context of great adversity, confusion and volatile political climate. Van Niekerk $(1996,446)$ states that the Heidelberg Catechism is an example of how Friedrich III opted for a confession confined to his territory. He had to show that he was part of a larger group of Reformers to counter the anti-Calvinistic measures of Emperor Maximilian issued in 1565. Strohm $(2014,20)$ mentions two crucial developments, which led to the drafting of the Heidelberg Catechism. Strohm $(2014,20)$ indicates that the conflict between the Protestants and Catholics during the First French War of Religion, between January and March of 1563, certainly played a fundamental role in the composition of the Heidelberg Catechism. A second significant development in the context of the drafting of the Heidelberg Catechism was the "serious disagreements" over the understanding of the Lord's Supper (Strohm 2014, 20). This was a significant issue, as the Lord's Supper was traditionally at the heart of the worship service, perceived as the most important sacrament in the mediation of salvation. The Reformers argued otherwise that salvation is mediated by consolatory words of promise, which are received in faith (Strohm 2014, 20). These opposing perspectives of the Lord's Supper even resulted in fistfights. One of the aims of the catechism was to counteract the teachings of the Roman Catholic Church and the Lutheran influence around the Lord's Supper.

Both Naudé (2003) and Kritzinger (2010), among others, have done extensive work to designate how the three principles of Belhar were living and confessed in the hearts of believers long before the drafting of Belhar in 1982. In an article called, "The Theological Coherence between the Belhar Confession and some Antecedent Church Witnesses in the Period 1948-1982," Naudé (2003) attempts to find theological coherences between Belhar, the DRMC Circuit of Wynberg's decision on apartheid

5 Arminianism is a branch of Protestantism based on the Dutch Reformed theologian Jacobus Arminius (1560-1609). It is a liberal reaction to the Calvinist doctrine of predestination. 
(1948); SA Catholic Bishop's Conference's statement on apartheid (1957); Cottesloe Consultation Statement (1961); SACC's Message to the People of South Africa (1968); Lutheran World Federation's statement, Southern Africa: Confessional Integrity (1977); charter of the Alliance of Black Reformed Christians in Southern Africa (ABRECSA) (1981); Open Letter by 123 Dutch Reformed Church pastors and theologians (1982); and World Alliance of Reformed Churches' Racism and South Africa (1982). Naudé (2003) indicates numerous correlations between Belhar and the documents as mentioned above, illustrating how these documents foreshadow the principles of unity, reconciliation and justice, as confessed in Belhar.

In his comparative study between Belhar and the Theological Declaration of the Belydende Kring (hereafter BK), Kritzinger (2010) highlights several similarities between the two documents. Kritzinger $(2010,216)$ states that some formulations indicate a word-for-word similarity between the Theological Declaration and Belhar and, in some cases, more general similarities. He believes that the drafters of Belhar quoted the BK Theological Declaration and that the similarities are cases of actual influence (Kritzinger 2010, 220). Van Rooi $(2008,8)$ concurs with Kritzinger that the Theological Declaration of the BK bears a solid resemblance to the later Belhar.

Strauss then, in my view, arrives at an accurate finding that the Reformed confessions confess their beliefs following Holy Scripture and confess the faith already living in the hearts of the believers. As in the case of the Three Forms of Unity confessed by the DRC, all three Reformed confessions did not attempt to bear any new beliefs around the Reformed faith. They drew from the Reformed beliefs previously made explicit by the Reformers and their understanding of Scripture. At most, the Three Forms of Unity just defined what the Reformers had voiced hitherto. In the same fashion, the former DRMC did not seek to include new convictions. Smit $(2012,187)$, a member of the commission responsible for drafting Belhar, conceded that the commission was convinced that it was not a moment for new theological arguments but to confess and encapsulate the faith and spiritual convictions already present in believers' hearts. Three convictions were seen as contradictory to the gospel of Jesus Christ: the unity of the church, the reconciliation in Jesus Christ, and God's justice.

Smit (1998, 7), one of the drafters of Belhar, explicitly states that it was not the intention of the drafters of Belhar to construct new theological arguments. The aim was to confess the faith already present and living in the heart of believers. The accompanying letter of Belhar explicitly states that the confession does not seek to produce new theological truths (Belhar 1986). Belhar is indeed a "people's confession"; as it was born "from 
below." "Belhar is a confession from the oppressed by the oppressed. It came from the heart of the church, not to be heard as a cry for help by whites, but rather a cry of pain, suffering, righteous anger and radical justice. Botman $(2008,15)$ agrees that Belhar arose from the underside of modern history, as it represents a Christian view on racism, natural division, and suffering from the context of those who suffer the realities of such human conditions.

\section{Critique against Belhar: Origin}

The origin of the Three Forms of Unity was briefly discussed in the previous section and will not be discussed here again. However, this section will focus on the DRC's critical evaluation and subsequent rejection of Belhar, based on its context of origin. Du Plooy $(2010,361)$ articulates this critique clearly, as he states that Belhar focuses on politics and the apartheid policy. Du Plooy $(2010,361)$ argues further that Belhar elevates these two aspects to the level of a Christian confession with which members' faith is tested.

Strauss (1997) agrees with Du Plooy (2010). Strauss (1997, 13) believes that the political context in which it originated makes Belhar time-bound, as the ideology of apartheid that was the primary reason for its emergence no longer exists statutorily and is not theologically defended by any Reformed church in South Africa. Horn (2013, 164) continues in the same vein when he states that both the DRC and the contemporary South African society have little resemblance to the church and society of 1982 . Horn $(2013,164)$ states that the extreme right-wing leaders left the DRC to form the Afrikaans Protestant Church, and apartheid is no longer part of the political environment. Is Belhar still relevant at all?

Strauss (2005) answers this question. Strauss $(2005,574)$ believes that even though Belhar mentions the term "apartheid," the accompanying letter and other pieces of the then DRMC around Belhar seem clear in each case about apartheid and its theological and moral justification. Strauss $(2005,574)$ categorically states that a particular societal order practice in no way comes down to confessional issues. For Strauss, Belhar is timebound since apartheid is both no more and a dominant slant in the genesis of Belhar.

Smit $(2012,185)$ states that the Protestant confessions cannot be understood in isolation from their historical moment and origin. Van Niekerk $(1996,446)$ continues in the same vein by emphasising the importance of taking the historical origins of confessions into account. He further notes that we will retain very few confessions if we were to condemn them based on their political-social context. All Three Forms of Unity were drafted and

6 This term was used by the German theologian Dietrich Bonhoeffer as he calls for the importance to view history and life from "the view from below." This view comes from the perspective of the outcasts, the suspects, the maltreated, the powerless, the oppressed, the reviled, and those who suffer. It focuses on the religious lives and pious practices of the laity and the ordinary faithful. This approach to history is interested in those left out, women, the socially inferior, the economically distressed, the politically marginalised, the educationally deprived, or the culturally unrefined. 
adopted with political motives. Belhar, like the Confessio Belgica, Heidelberg Catechism and the Canons of Dort, emerged in a particular historical context, confessing the faith according to Scripture when the Reformed faith and the credibility of the gospel were at stake. Furthermore, like the Three Forms of Unity, Belhar is not bound by or to its particular context of origin. Durand (1984) emphasises this exact point concerning Belhar in his contribution, "Is a Confession Really Necessary?"

A confession dare not engage with mere trivialities. It can only be an extension of the church's ancient confession that Jesus is Lord. This is the guarantee of the continued relevance of the confession. ... For this reason, I am convinced that the Confession of Belhar will outlive apartheid and the heresy that led to it and will retain its message. The three core issues at stake here, unity, reconciliation and justice, are close to the heart of the gospel. (Durand 1984, 46)

Durand $(1984,46)$ states that "a true confession rises above the circumstances of its time." As such, Durand argues that the church does not "simply confess with the immediate situation in mind, but with an eye on the future" (Durand 1984, 46).

Neither the DRMC/URCSA nor the drafters of Belhar ever staked the claim that Belhar was created ex nihilo. Boesak $(2015,239)$ states that the birth of Belhar was a process borne by the development of theological thinking of a "confessing church" as in the thinking of the Christian Institute. The truths of confessions do not depend on the historical moment of the origin or its possible usefulness and significance for the social, political and ecclesiastical context. Instead, the aptness of a confession solely rests upon the question of whether or not the gospel is heard correctly in a moment of controversy (Smit 2012, 185). Botman $(2008,15)$ asserts that Belhar lifts the heart of the gospel as a testimony of hope in the context of the complete human condition. Belhar's timelessness lies in its significance. It helps us read our world, the condition humanity has manoeuvred itself into and especially the suffering that we see worldwide in a new way (Botman 2008, 15). Belhar was and affirmed that the lives of black people matter in all circumstances because it speaks of good news in a divided world where hatred reigns. The message of hope is woven together in the gift of and the calling to unity, reconciliation, and justice in a world besieged with disunity, inequality and exploitation (Botman 2008, 15).

Plaatjies-Van Huffel (2014) stresses the importance of reading Belhar within its historical context. This is not to say that Belhar is time-bound or confined to its environment of origin. Plaatjies-Van Huffel $(2014,320)$ warns that the original meaning of Belhar can become lost if taken out of its original context. Belhar represents a Christian view on racism and suffering from the perspective of those who suffered the realities of such inhumane conditions (Plaatjies-Van Huffel 2014, 320). This representation enables Belhar to be "used [as] discursive instrument in the reconciliation processes between different racial groups, minority groups, locally and abroad" (Plaatjies-Van Huffel 2014, 320). Plaatjies-Van Huffel $(2014,320)$ agrees with Durand that racial inequality, discrimination, oppression, poverty and injustice, as addressed by 
Belhar, are timeless and universal themes. Boesak $(2015,101)$ shares similar thoughts by stating that a contextual reading of Belhar reveals its continued relevance within the situations of wealth, poverty and the extreme inequalities in our local and global societies. Belhar addresses new struggles for ecological, socio-economic, cultural and gender justice that stretch beyond racial discrimination (Boesak 2015, 101).

Boesak $(2015,101)$ mentions that Belhar was born in a "moment of truth"; and its truth transcends that moment, both in time and in circumstance. For this reason, reading Belhar as a historical document permits the interpretation of the past by furnishing the tools to interpret the world in which we find ourselves. Boesak $(2015,101)$ agrees with Plaatjies-Van Huffel that the truth of Belhar can reveal the truth in and for other moments too. Belhar's prophetic nature and its ability to address universal challenges have been recognised and acknowledged beyond the perimeters of URCSA and South Africa, as various churches around the world have claimed Belhar as their own.

\section{Critique against Belhar: Black Liberation Theology}

The third and final critique contends that Belhar is a champion of liberation theology or its association with the "work of Boesak" (Kritzinger 2010, 210). Strauss (1997, 13) mentions that Belhar has a solid horizontal tendency, thus neglecting the vertical dimension. Strauss refers to the fourth part of Belhar where, according to him, liberation theology is closely present, especially where it is confessed "that in a world full of injustice and enmity He is in a special way the God of the needy, the poor and the oppressed, and that He calls His church to follow Him in this ..." (Belhar 1986). ${ }^{7}$ The DRC in Namibia soon followed suit and downgraded Belhar as liberation theology (Plaatjies-Van Huffel 2017, 27). The DRC requested the drafters on various occasions to amend this clause because of the opinion that this section could have been formulated differently (Botha and Naudé 1998, 83). Naudé $(2012,150)$ states that this view has

7 The full article 4 of Belhar reads as follows: "We believe that God has revealed Godself as the One who wishes to bring about justice and true peace on earth; that in a world full of injustice and enmity God is in a special way the God of the destitute, the poor and the wronged and that God calls the church to follow in this; that God brings justice to the oppressed and gives bread to the hungry; that God frees the prisoners and restores sight to the blind; that God supports the downtrodden, protects the strangers, helps orphans and widows and blocks the path of the ungodly; that for God pure and undefiled religion is to visit the orphans and the widows in their suffering; that God wishes to teach the people of God to do what is good and to seek the right; that the church must therefore stand by people in any form of suffering and need, which implies, among other things, that the church must witness against and strive against any form of injustice, so that justice may roll down like waters, and righteousness like an everflowing stream; that the church, belonging to God, should stand where God stands, namely against injustice and with the wronged; that in following Christ the Church must witness against all the powerful and privileged who selfishly seek their own interests and thus control and harm others. Therefore, we reject any ideology which would legitimate forms of injustice and any doctrine which is unwilling to resist such an ideology in the name of the gospel" (Belhar Confession 1986). 
been and is still used to discredit Belhar as "liberation theology" built on the notion of a Marxist class struggle. ${ }^{8}$

Smit $(1998,10)$ explains that the reference to God and, in particular, the God of the needy, poor and oppressed should not be seen and explained from the view of liberation theology. The criticism against this clause remained that it was strongly politically motivated, especially from the liberation theology. Du Plooy $(2010,363)$ maintains that the horizontalisation of reconciliation and justice is observable in Belhar, especially when tested against the Scriptures and Three Forms of Unity.

Smit $(1998,10)$ states that the expression that God "is in a special way the God of the needy, the poor and the oppressed" was questioned by the synod of the DRMC in 1982. Adonis $(2006,237)$ affirms this objection against this formulation. According to Smit, someone asked that the synod instead should opt for an expression from liberation theology, in which God is the God of the poor, or that God is on the side of the poor. Smit $(1998,10)$ states the commission responsible for drafting the confession explained that they did so deliberately because both of these expressions resonate with liberation theology and sound as if they were based on a class struggle in society. This will effectively mean that God would only be on the side of some and against others. This would not be an expression of the faith of the members of the NGSK (Smit 1998, 10). The chosen words only wanted to confess the universal Christian belief that God had revealed Himself as "the Help of the helpless" because that in itself would fundamentally refute any attempt to legitimise apartheid theologically.

The idea of God who chooses sides is one not foreign to the DRC or the white Afrikaansspeaking people. It has always been an integral part of the DRC's justification of apartheid that God chose and ordained whites' tutelage over blacks. Nowhere is it as clear as with the Voortrekkers and Day of the Vow at Blood River's battle. ${ }^{9}$ Van der Merwe $(2014,141)$ states that the belief that God intervened at Blood River and gave the Voortrekkers the victory, confirmed to the Voortrekkers that God chose them and that they are God's chosen people. Van der Merwe $(2014,141)$ states that this belief made the Vow one of the cornerstones of Afrikaner Nationalism, which played a significant role in the history of the members of the DRC in the twentieth century. Members of the white Afrikaans-speaking constituency still devotedly celebrate the Day of the Vow, thereby still celebrating God's "choosing" of the Afrikaners. It comes as no surprise that a church and people still celebrating the Day of the Vow finds article 4 of Belhar problematic. Suppose God has chosen the Afrikaners at Blood River; how is it possible that God will choose the poor, the downtrodden and the marginalised. Belhar

8 See Botha and Naudé 2011. Good News to Confess. The Belhar Confession and the Road of Acceptance. Wellington: Bible Media, 86-88, for a discussion on Belhar and liberation theology.

9 The Voortrekkers asked God to give them victory over the Zulus at Blood River. In return, they would build a church building, and they and their generations to celebrate this day as a day of thanksgiving. 
confronts this nationalistic belief and presents a possible problem for those who still celebrate the Day of the Vow.

The expression "in a special way" is therefore of crucial importance (Smit 1998, 10). Smit reiterates that this means that God does love all people. However, at the same time, the Bible testifies in countless ways that God is for that very reason about those in need, about the weak, the victims, the suffering, the widows and orphans, the poor and marginalised, the afflicted and the hungry, the deaf and the blind. Unfortunately, the critics of Belhar ignore the fact that the words "in a special way" repeatedly claim that Belhar simply says that God is "the God of the poor." This critique has often led the DRC to overlook how Belhar is deeply embedded in the Reformed confessional tradition. Vosloo $(2017,274)$ mentions that Belhar bears strong analogies with the ecclesiology put forward in the Confessio Belgica (articles 28 and 29) and the Heidelberg Catechism (Sunday 21, question and answer 54 and 55). He further argues that the ecclesiology of articles 54 and 55 of the Heidelberg Catechism was, therefore, part of the theological imagination that produced this document (Vosloo 2017, 274).

In an open letter, written in response where 35 ministers of the DRC lamented the Free State synod's decision not to incorporate Belhar in article 1 of their church order, Louw (2015) disagrees with Smit as he states that article 4 of Belhar does manifest strong parallels with liberation theology and one has to be either ignorant or naïve not to interpret it as such. According to Louw, article 4 is ambiguous and opens the door to an interpretation related to liberation theology, even though Smit declared that this is not the case. Louw (2015) discards Belhar as a confession of faith based on this solitary assumption of ambiguity. ${ }^{10}$ Louw draws a direct association between liberation theology and the person and work of Boesak as one of the drafters of the confession.

It is indeed true that the South American liberation theology has significantly influenced Boesak. Boesak's doctoral dissertation bore the title "Farewell to Innocence." This study was a social-ethical study on black theology, black power and black consciousness (Fortein 2013, 303). Even the DRMC experienced the emergence of black liberation theology since the late 1970s. A report on "Black Power and Black Theology" was tabled at both the DRMC synods of 1978 and $1982 .{ }^{11}$ In retrospect, it is evident how these reports and black theology influenced the DRMC onwards (Plaatjies-Van Huffel 2014, 311). The 1978 synod is a landmark in the church's history as it altered the course of the DRMC. It has already been indicated that the DRMC declared apartheid theological heresy in 1978. Since then, the DRMC witnessed prophetically against

10 Louw's argument reads as follows, "Ongeag van die kommissie se gevolgtrekking dat ons Artikel 4 nie as bevrydingsteologie hoéf te interpreteer nie, sê hulle duidelik dat mens dit so kán interpreteer. En dit is ' $n$ ongelooflike groot probleem. ' $n$ Belydenisskrif moet eerstens op duidelike en ondubbelsinnige wyse dit wat die Bybel leer weergee. Indien dit nie duidelik en ondubbelsinnig is nie kwalifiseer ' $n$ dokument eenvoudig nie as ' $n$ belydenisskrif nie, omdat dit dan die deur vir onsekerheid en dwaalleer in die kerk oopmaak" (Louw 2015).

11 See Agenda en Handelinge NGSK 1978, 269-298; 1982, 377-380. 
apartheid with clear and far-reaching decisions on various discriminatory laws like the repeal of the Group Areas Act of $1950^{12}$; The Immorality Amendment Act of $1950^{13}$; and the Prohibition of Mixed Marriages Act of $1968 .{ }^{14}$ Fortein $(2015,122)$ lists the influence of Steve Biko, the black consciousness movement, and black liberation theology as the chief contributors to this enormous paradigm shift, especially considering the theological and political climate of the time.

This article maintains that Belhar unashamedly stands in both the Reformed and black liberation traditions, as it is the culmination of theological thought and struggle for the identity of black people in South Africa since the dark days of colonialism. The theology that informed Belhar, in my view, was directly rooted in liberation theology. Boesak $(2015,100)$ states that for an entire generation, this unique brand of black liberation theology, inspired by the rediscovery of the Reformed theology of the radical John Calvin, became the bedrock of theological reflection and action. In Belhar, we find the outlook of black people's existence trapped in a world of systemic racism, dehumanisation, exploitation and exclusion. James Cone states the following on black theology that is so powerfully present in Belhar:

Black theology is the religious explication of black people's need to redefine the scope and meaning of black existence in a white racist society. Black power focuses on the political, social and economic condition of black people, seeking to define the meaning of black self-determination concretely.... Black theology puts black identity in a theological context, showing that black power is not only consistent with the gospel of Jesus Christ: it is the gospel of Jesus Christ. (Cone 1993, 106)

Black liberation theology's focus on the poor and the marginalised is no new theology. Boesak writes the following in this regard:

It is the proclamation of the age-old gospel, but now liberated from the deadly hold of the mighty and the powerful and made relevant to the situation of the oppressed and the poor. One can say that it represents a new way of theologising, a new way of thinking. (Boesak 1976, 15)

Black liberation theology takes its cue from Israel's liberation events in the book of Exodus and places the gospel in the perspective of liberation. It seeks to proclaim the gospel as the gospel of the poor. It interprets the God of the Bible as a God of deliverance rather than oppression; as a God of law rather than injustice; as a God of freedom and humanity rather than addiction and submission; a God of love, justice and brotherhood rather than a God of hatred, self-interest and exploitation (Boesak 1976, 15). Moore correctly asserts when he refers to black theology: "It is a theology of the oppressed, by the oppressed, for the liberation of the oppressed" (Moore 1973, ix). Black theology

12 This Act legalised residential separation between the different racial groups.

13 This Act prohibited unmarried sexual relations between whites and blacks.

14 This Act invalidated any marriage entered outside of South Africa between people of different racial groups. 
then wants to serve as an antidote to blacks' spiritual captivity and is, therefore, against the loss of human dignity. Moore (1973) confirms that black theology seeks new symbols to restore human dignity to blacks. It is a fitting theology for people living within a reality of slavery, injustice, and poverty. The "black" referred to in black theology refers to a state and condition of oppression, not only a colour. This theology underpins Belhar.

The opponents of Belhar are, in my view, correct in their assumption that black liberation theology strongly influenced Belhar, particularly in article 4. God is never neutral. God always chooses sides. God is in a special way the God of the poor, marginalised, the destitute and the wronged. God reveals God-self in the Person of Jesus Christ of Nazareth, a first-century Jew in occupied Palestine. Van Aarde (2001) reminds us of this Jesus in his quest for the historical Jesus, who was fatherless in Galilee. The focal point of Van Aarde's research is his demonstration that he grew up fatherless and that Jesus' father, Joseph, should be seen as a legendary figure $(2001,4)$. The consequences of Jesus' fatherlessness would have been immense within the context of the first century. This meant that Jesus would have been excluded from being called a "child of Abraham"; that is, a child of God; he would have been denied access to the court of the Israelites in the temple, and he would have been excluded from the privilege of being given a daughter in marriage (Van Aarde 2001, 4). This drives home the fact the Jesus, being confessed by many as the Messiah of Israel, as Lord of the world, as the Child of God, as God, is inextricably bound up in the Jesus of history (Van Aarde 2001, 8). The understanding that the historical context Jesus lived in and responded to was the reality of the Roman Empire, often lacks in Westernised theology. Boesak $(1984,12)$ agrees with Van Aarde as he states that the image of Jesus, as presented in the New Testament, identifies to a remarkable degree with the black experience. Boesak emphasises this point as follows:

Is Jesus really as "Western" as the "civilisation" that claims him? Is the Jesus whom thousands of our ancestors learned to know while they worked on plantations as slaves identified with the power and oppression of whites? If this picture of Jesus is true and real, then Jesus is white and he is unacceptable to blacks. The Jesus who represents the God of the Bible cannot be the same one whose name was carved into bows of the Dutch slave ships in which Africans were transported to their death. For black Christians, as James Cone has said, the only authentic confession in our age is the confession of Jesus Christ as the Black Messiah. (Boesak 1984, 11-12)

Belhar seeks to interpret the black existence of oppression and exclusion through the eyes and experience of the poor, fatherless Jesus. This Jesus is, for all ends and purposes, the Black Messiah.

\section{Conclusion: Why not Belhar?}

This article addressed some of the chief objections to the inclusion and acceptance of Belhar in the confessional basis of the DRC. This study by no means exhausted the 
critique presented in this article. Nor does it argue that these are the only objections put forward in the process of church reunification. The article presented the following as some of the main critique against Belhar: Belhar confesses nothing new; the sociopolitical origins and Belhar's connection with black theology. The study attempted to indicate how Belhar is no different in its content and origin from the Three Forms of Unity. Strauss $(2005,574)$ and many opponents of Belhar surprisingly agree that much of the content of Belhar seems to be Scriptural. Belhar was compared to the origins of the Three Forms of Unity, thereby emphasising that Belhar, like the other Reformed confessions, originated within a particular context but is not bound to that context. The study further illustrates that Belhar is rooted in black theology. It seeks to interpret the black experience "from below" and how it constitutes a black initiative towards unity, justice and reconciliation.

The question is: Why not Belhar? If Belhar is as scriptural, as timeless and as Reformed as the Three Forms of Unity, why not Belhar? If Belhar gives a voice to those who have been voiceless for so long in this country, why not Belhar? Why does the DRC not reunite with those black churches like the DRCA, RCA, Calvin Protestant Church, among others, who do not confess Belhar as part of their confessional basis? Is Belhar the main barrier hampering church reunification, or is it still perhaps the "weakness of some?"15 This study indicates that it might be the latter.

\section{Autobiographic Note}

Eugene Andre Fortein is a lecturer in Church History, at the Faculty of Theology and Religion, University of the Free State, South Africa.

\section{References}

Acts of General Synod of the Dutch Reformed Church. 1990.

Acts of General Synod of the Dutch Reformed Church. 2013.

Agenda en Handelinge NGSK. 1978.

Agenda en Handelinge NGSK. 1982.

Agenda en Handelinge VGKSA. 2008.

Adonis, J. C. 2006. "The History of Belhar.” Nederduitse Gereformeerde Teologiese Tydskrif 47 (1\&2): 234-239.

Belhar Confession. 1986.

15 The term "weakness of some" refers to the racial prejudice of white members during the 1857 decision of synod to include people of colour in existing white congregations. Synod decided that where this inclusion is not possible due to the "weakness of some," separate buildings need to be erected for separate worship. 
Boesak, A. A. 1976. Farewell to Innocence. A Social-Ethical Study on Black Theology and Black Power. Kampen: Uitgeversmaatschapij J. H. Kok.

Boesak, A. A. 1984. Black and Reformed. Apartheid, Liberation and the Calvinist Tradition. New York: Orbis Books.

Boesak, A. A. 2011. "To Stand where God Stands: Reflections on the Confession of Belhar after 25 years." Studia Historiae Ecclesiasticae 34 (1), 143-172.

Boesak, A. A. 2015. Kairos, Crisis and Global Apartheid. The Challenge to Prophetic Resistance. New York: Palgrave Macmillan. https://doi.org/10.1057/9781137495310.

Botman, H. R. 2008. "The Confession of Belhar and Our Common Future perspectives." Perspectives 23 (5): 14-16.

Botha, J., and P. Naudé. 1998. Op Pad met Belhar: Goeie Nuus vir Gister, Vandag en More. Van Schaik Publishers.

Botha, J., and P. Naudé. 2011. Good News to Confess. The Belhar Confession and the Road of acceptance. Wellington: Bible Media.

Cloete, G. D., and D. J. Smit. 1984. A Moment of Truth: The Confession of the Dutch Reformed Mission Church 1982. Grand Rapids, Michigan: Eerdmans.

Cone, J. 1993. "Black Theology and the Black Church: Where Do We Go from Here?" In Black Theology and Black Liberation, edited by J. Cone and G. Wilmore. Maryknoll, NY: Orbis Books.

Cornelissen, E. 2013. "Rondom die Belhar-Belydenis: 'n Studie van Argumente.” Unpublished Master's Degree essay.

Die Kerkbode. 2015.

Du Plooy, A. 2010. "Die Belydenis van Belhar en die Ekumene teen die Agtergrond van die Drie Formuliere van Eenheid." In die Skriflig 44 (2): 349-368. https://doi.org/10.4102/ids.v44i2.151.

Durand, J. J. F. 1984. “A Confession: Was it Really Necessary?” In A Moment of Truth: The Confession of the Dutch Reformed Mission Church, 33-41, edited by G. D. Cloete and D. J. Smit. Grand Rapids: WB. Eerdmans.

Fortein, E. A. 2013. "Allan Boesak and the Dutch Reformed Mission Church between 1979 and 1990." In Reformed Churches in South Africa and the Struggle for Justice: Remembering 1960-1990, 303-315, edited by Plaatjies-Van Huffel, Mary-Anne E. and R. Vosloo. Stellenbosch: SUN Press. 
Fortein, E. A. 2015. "Allan Boesak en die Nederduits Gereformeerde Sendingkerk." Unpublished doctoral dissertation. University of Stellenbosch.

Horn, N. 2013. "The Belhar Confession: 29 Years on.” Nederduitse Gereformeerde Teologiese Tydskrif 54 (3\&4) 157-167. https://doi.org/10.5952/54-0-352.

Kritzinger, K. 2010. “Celebrating Communal Authorship: The Theological Declaration of the Belydende Kring (1979) and the Belhar Confession. In honour of Simon Maimela and in memory of Chris Loff." Studia Historiae Ecclesiasticae 34: 209-231.

Louw, W. 2015. “Antwoord op die 35 Vrystaatse Predikante se Verklaring. 'n Ope Brief aan alle pro-Belhar Lidmate van die NG Kerk. 'Hier Staan ek'.” Accessed September 14, 2020. https://hierstaanek.files.wordpress.com/2015/03/belhar-brief.pdf.

Moore, B. (Ed.). 1973. Black Theology. The South African Voice. London: Hurst \& Company.

Naudé, P. 2003. "The Theological Coherence between the Belhar Confession and some Antecedent Church Witnesses in the period 1948-1982." Verbum et Ecclesia 24 (1): 156179. https://doi.org/10.4102/ve.v24i1.319.

Naudé, P. 2012. "The Belhar Confession and Church and Society: A Comparative Reading in Five Statements.” Acta Theologica 32 (2): 147-161. https://doi.org/10.4314/actat.v32i2.9.

Plaatjies-Van Huffel, Mary-Anne E. 2014. "The Belhar Confession in its Historical Context." Nederduitse Gereformeerde Teologiese Tydskrif 55 (1): 301-324. https://doi.org/10.5952/55-1-2-527.

Plaatjies-Van Huffel, Mary-Anne E. 2017. “Acceptance, Adoption, Advocacy, Reception and Protestation: A Chronology of the Belhar Confession." In Belhar Confession: The Embracing Confession of Faith for Church and Society, 1-96, edited by Plaatjies-Van Huffel, Mary-Anne E. and L. Modise. Stellenbosch: SUN Press. https://doi.org/10.18820/9781928357599.

Smit, D. J. 1998. "Die Belydenis van Belhar: Ontstaan, Inhoud, Resepsie, Relevansie.” Studientagung 15-17. Accessed September 14, 2020. http://www.kaapkerk.co.za/wp/wpcontent/uplouds/detmold.belhar.praatjie.afr.doc.

Smit, D. J. 2012. “Oor die Teologiese Inhoud van die Belydenis van Belhar.” Acta Theologica 32 (2): 184-202. https://doi.org/10.4314/actat.v32i2.11.

Strauss, P. J. 2005. "Belydenis, Kerkverband en Belhar.” Nederduitse Gereformeerde Teologiese Tydskrif 46 (3\&4): 560-575.

Strauss, P. J. 2006. "Skrif, Belydenis en die Aard van Kerkverband.” Nederduitse Gereformeerde Teologiese Tydskrif 47 (1\&2): 103-111.

Strauss, S. A. 1997. “'n Teologiese Beoordeling van die Belharbelydenis.” Unpublished paper delivered at a minister's conference, August 1997, Bloemfontein. 
Strohm, C. 2014. "On the Historical Origins of the Heidelberg Catechism." Acta Theologica (20): 16-34. https://doi.org/10.4314/actat.v20i1.2S.

Van Aarde, A. G. 2001. Fatherless in Galilea: Jesus as Child of God. Harrisburg: Trinity Press International.

Van Der Merwe, J. 2014. "From 'Blood River' to 'Belhar': A Bridge too far." Studia Historiae Ecclesiasticae 40 (1): 137-155.

Van Niekerk, A. C. J. 1996. "Moet ons die Belydenis van Belhar (1986) as 'n nuwe Belydenisskrif Aanvaar?" Skrif en Kerk 17 (2): 443-455. https://doi.org/10.4102/ve.v17i2.530.

Van Rooi, L. B. 2008. “To Obey or Disobey? The Relationship Between Church and State During the Years of Apartheid. Historical Lessons from the Activities of the Belydende Kring (1974-1990).” Studia Historiae Ecclesiasticae XXXIV (1): 173-191.

Vosloo, R. 2017. Reforming Memory. Essays on South African Church and Theological History. Stellenbosch: Sun Press. https://doi.org/10.18820/9781928314370. 